\title{
Lipemic Index
}

National Cancer Institute

\section{Source}

National Cancer Institute. Lipemic Index. NCI Thesaurus. Code C111242.

The determination of the amount of abnormally high concentration of lipid present in a sample. 